\title{
CORPORATE GOVERNANCE, WHISTLE BLOWING POLICY DAN EARNINGS MANAGEMENT PADA PERUSAHAAN JASA DI INDONESIA
}

\author{
Dian Indriana Hapsari* \\ Fakultas Ekonomi dan Bisnis, Universitas Dian Nuswantoro \\ email:dian.indriana@yahoo.com
}

\begin{abstract}
Corporate Governance mechanisms are not able to effectively mitigate Earnings Management. Whistleblowing Policy can play a role in carrying out effective functional governance so that it is expected to be able to reduce Earnings Management activities significantly. This study aims to examine whether the corporate governance mechanism in a company that implements Whistleblowing Policy is more effective in limiting Earnings Management than companies that do not implement Whistleblowing Policy. The study method used is descriptive-associative. The sample in this study was manufacturing companies listed on the Indonesia Stock Exchange in 2016-2018. This research results in findings that the Corporate Governance mechanism is more effective in companies that have a Whistleblowing Policy than companies that do not have a Whistleblowing Policy. The flow of information before the Whistleblowing Policy occurs a significant effect. Likewise, company size and leverage also have a substantial impact on Earnings Management. Meanwhile, there is no effect on the number of independent commissioners on Earnings Management.
\end{abstract}

Keywords: Corporate Governance, Earnings Management, Whistleblowing Policy

\begin{abstract}
ABSTRAK
Mekanisme Corporate Governance tidak mampu memitigasi Earnings Management secara efektif. Whistleblowing Policy dapat berperan dalam melakukan tata kelola fungsional yang efektif sehingga diharapkan mampu mengurangi aktivitas Earnings Management secara signifikan. Studi ini bertujuan untuk menguji apakah mekanisme Corporate Governance di suatu perusahaan yang menerapkan Whistleblowing Policy lebih efektif dalam membatasi Earnings Management daripada perusahaan yang tidak menerapkan Whistleblowing Policy. Metode studi yang dipakai yakni deksriptif-asosiatif. Sampel dalam penelitian ini adalah perusahaan manufaktur yang terdaftar di Bursa Efek Indonesia tahun 2016-2018. Penelitian ini menghasilkan temuan bahwa mekanisme Corporate Governance lebih efektif di perusahaan yang memiliki Whistleblowing Policy daripada perusahaan yang tidak memiliki Whistleblowing Policy. Aliran informasi sebelum terjadi Whistleblowing Policy memiliki pengaruh signifikan. Demikian halnya dengan size dan leverage perusahaan yang juga berpengaruh signifikan terhadap Earnings Management. Sedangkan tidak terdapat pengaruh jumlah komisaris independen terhadap Earnings Management.
\end{abstract}

Kata Kunci: Corporate Governance, Earnings Management, Whistleblowing Policy 


\section{PENDAHULUAN}

Skandal dan penipuan dalam praktik akuntansi kerap terjadi di era globalisasi. Fleksibilitas standar akuntansi memungkinkan pihak manajemen memanipulasi laba dalam batasan-batasan hukum yang berlaku. Praktik tersebut memaksa manajemen terlibat dalam pelaporan informasi akuntansi yang tidak akurat.

Berbagai fenomena pelaporan informasi akuntansi yang tidak akurat banyak terjadi di Indonesia. Misalnya kasus PT Jiwasraya sejak tahun 2008. Beberapa Kantor Akuntan Publik (KAP) berusaha menutupi kasus Jiwasraya tersebut, mulai dari KAP Soejatna, Mulyana dan Rekan (2006) hingga yang terbaru KAP Tanudiredja, Wibisana, Rintis dan Rekan (2016-2017). Laporan yang diinformasikan KAP-KAP tersebut kepada publik yakni bahwa perusahaan dalam keadaan sehat. Informasi tersebut patut dicurigai, mengingat adanya unsur kecurangan dalam kasus Jiwasraya.

Sebelum Jiwasraya, masih terdapat kasus fraud di Asuransi Bumiputera yang hingga kini belum menemukan penyelesaian. Diduga modus yang digunakan sama, yakni bermain saham dengan berkolusi pada emiten yang sahamnya sulit diperdagangkan. Francis et al. (2008) dalam studinya mengemukakan bahwa perusahaan yang pengungkapan labanya baik akan cenderung menyediakan pengungkapan sukarela lebih tinggi daripada perusahaan yang labanya rendah.

Perhatian para peneliti terhadap Earnings Management telah beralih ke Corporate Governance. Mekanisme Corporate Governance meliputi Dewan Direksi, Kepemilikan dan Komite Audit disebut dapat mengurangi persoalan keagenan praktik Earnings Management. Akan tetapi pada implementasinya, mekanisme Corporate Governance tidak cukup kuat untuk mengurangi permasalahan agensi. Faktor yang menyebabkan yakni adanya konflik kepentingan dalam manajemen dan asimetri informasi pada organisasi. Selain itu, adanya kesenjangan dalam mekanisme Corporate Governance dikarenakan banyak anggota dewan bekerja penuh waktu di perusahaan lain sehingga menggantungkan perolehan informasi pada CEO dalam memantau keputusan manajer.

$\begin{array}{ccc}\begin{array}{c}\text { Kondisi } \\ \text { menunjukkan }\end{array} \text { bahwa } & \begin{array}{c}\text { demikian } \\ \text { Corporate }\end{array}\end{array}$ Governance bukanlah mekanisme yang paling efektif dalam mengendalikan keputusan dalam perusahaan. Saat Dewan Direksi memiliki akses yang mudah terhadap informasi, mekanisme Corporate Governance secara efektif akan membatasi aktivitas Earnings Management. Oleh sebab itu, penting bagi Dewan untuk mencari informasi dari manajer tingkat bawah tentang keputusan dan kegiatan manajer puncak.

Guna mendukung hal tersebut, diperlukan kebijakan untuk mendukung dan memperkuat relasi antara mekanisme Corporate Governance dengan fungsi audit internal. Whistleblowing Policy diajukan sebagai bagian penting dari sistem kontrol internal untuk meningkatkan peran pemantauan mekanisme Corporate Governance. Studi-studi sebelumnya menghasilkan bahwa mekanisme Corporate Governance tidak mampu memitigasi Earnings Management secara efektif. Whistleblowing Policy dapat berperan dalam melakukan tata kelola fungsional yang efektif sehingga diharapkan mampu mengurangi aktivitas Earnings Management secara signifikan.

Studi ini bertujuan untuk menguji apakah mekanisme Corporate Governance di suatu perusahaan yang menerapkan Whistleblowing Policy lebih efektif dalam membatasi Earnings Management daripada perusahaan yang tidak menerapkan Whistleblowing Policy. Penelitian ini adalah studi empiris pertama yang mengimplementasikan teori agensi dan 
sumber daya dalam dalam pengujian peran pemantauan Corporate Governance terhadap pembatasan Earnings Management melalui Whistleblowing Policy. Penelitian ini sebagai variabel intervening yang menggunakan objek penelitiannya adalah perusahaan manufaktur yang terdaftar di Bursa Efek Indonesia tahun 2016-2018.

\section{KAJIAN LITERATUR}

\section{Teori Keagenan (Agency Theory)}

Teori keagenan membagi pengelolaan perusahaan yang berbentuk Perseoran Terbatas (PT) ke dalam pengelola dan pemilik. Pengelola kerap disebut manajemen atau agen, sedangkan pemilik atau pihak yang memegang saham disebut sebagai principal. Pembagian ini menimbulkan masalah keagenan (agency problem) saat perusahaan bangkrut. Problema tersebut muncul dalam dua permasalahan, yakni antara pemilik saham dengan pemilik obligasi dan antara pemilik saham dengan pihak manajemen (Husnan \& Pudjiastuti, 2012).

Konflik antara manajer dengan pemegang saham terjadi saat manajemen tidak punya saham mayoritas. Antara keduanya berusaha meningkatkan kemakmuran masing-masing, pemilik saham memanfaatkan manajer namun manajer bertindak untuk mencapai kemakmurannya sendiri. Maka, pemilik saham harus mengeluarkan agency cost untuk memonitor kegiatan manajer (ukuran perusahaan), mencegah timbulnya pengeluaran tak perlu seperti utang dan pembelin aset.

Mengacu pada teori keagenan, mekanisme Corporate Governance mampu membantu menyelesaikan persoalan agensi. Selain itu, dari perspektif teori ketergantungan sumber daya (resource depenedence), mekanisme Corporate Governance adalah alat strategis yang membantu untuk menghubungkan sumber daya eksternal ke perusahaan.

\section{Whistleblowing}

Mengacu pada pendapat Brandon (2013), whistleblowing ialah aksi yang dilaksanakan seorang pegawai atau beberapa pegawai dengan tujuan melakukan pembocoran atas pelanggaran yang umumnya terkait finansial oleh pimpinan atau perusahaan tempatnya bekerja, informasi tersebut dilaporkan kepada pihak lain. Saat mengungkapkan kecurangan atau whistleblowing kerap bersifat confidential dan harus dilakukan berdasarkan itidak baik, bukan semata untuk keuntungan pribadi (KNKG, 2008).

$$
\text { Brandon (2013) membagi }
$$

whistleblowing ke dalam dua tipe, yakni internal dan eksternal. Whistleblowing internal dilakukan oleh karyawan dengan melaporkan tindak kecurangan ke atasan perusahaan yang ada di atasnya demi atas dasar motivasi moral dan mencegah kerugian perusahaan. Whistleblowing eksternal ditandai dengan pelaporan kecurangan perusahaan yang dilaksanakan pekerja kepada publik demi mencegah kerugian yang menimpa konsumen atau masyarakat.

Orang yang menginformasikan pelanggaran dalam organisasi atau whistleblowing disebut whistleblower (Muhammad, 2015). Namun, orang yang berani menjadi whistleblower tidaklah banyak disebabkan adanya risiko ancaman penurunan jabatan atau pemutusan hubungan kerja.

\section{Whistleblowing System}

Sistem whistleblowing atau whistleblowing system berwujud suatu aplikasi yang memiliki fungsi dalam memberikan laporan atas tindak pelanggaran. Antara perusahaan dengan pemerintah mempunyai whistleblowing system yang umumnya berbeda. Pada pemerintah, whistleblowing system diaplikasikan melalui WiSe sebagai laman situs resmi pemerintah. Pada perusahaan, aplikasi yang difungsikan telah dirancang 
sedemikian rupa dengan kekhususan masing-masing sesuai kebutuhan whistleblowing system perusahaan.

Penyedia aplikasi whistleblowing system pada instansi pemerintahan adalah Kementerian Keuangan. Siapa saja yang mempunyai informasi yang hendak dilaporkan, mislanya informasi perihal tindakan berindikasi penipuan pada instansi pemerintah. Sedangkan acuan pelaporan dalam sektor swasta dijabarkan melalui Pedoman Sistem Pelaporan Pelanggaran Komite Nasional Kebijakan Governance (KNKG) tahun 2008. Pihak yang dituju saat whistleblower melaporkan tindak pelanggaran di sektor swasta bukan instansi khusus dalam penanganan laporan. Namun, perusahaan swasta wajib menerapkan sistem laporan yang memiliki spesialisasi tersendiri dan pengelolaannya diserahkan oleh perusahaan yang bersangkutan.

Whistleblowing system terdiri atas tiga elemen (Australian Standards 8000 dalam Daniri, 2007). Pertama, elemen struktural yakni komite organisasi khusus yang menangani whistleblowing sebagai usaha perlindungan kepada whistleblower sebagaimana tercantum dalam UU Nomor 13 tahun 2006 tentang Perlindungan Saksi dan Korban. Kedua, elemen operasional yakni sistem pengkomunikasian laporan yang aman, kerahasiaan terjamin, dan cepat, serta pengaksesannya mudah dilakukan oleh siapa saja. Ketiga, elemen maintenance yakni pendidikan dan pelatihan yang berkesinambungan guna meningkatkan kemampuan investigator.

Adapun mekanisme dalam whistleblowing system melalui tahapan intake atau pelaporan, retention atau pencatatan pelaporan, dan treatment atau pemrosesan laporan (Bloch dalam Daniri, 2007). Pada tahap pemrosesan, terdapat proses communication, evaluation, investigation, report, dan coorective action.

Amri (2008) menyebutkan bahwa sistem whistleblowing bisa dinyatakan memiliki efektivitas jika mampu meminimalisasi banyaknya kecurangan usai penerapan program sistem whistleblowing dalam kurun periode tertentu. Efektivitas diterapkannya whistleblowing system bergantung pada tiga hal, antara lain (1) Situasi yang memungkinkan pekerja mengetahui atau menyaksikan tindak curang dan bersedia melakukan pelaporan; (2) Perusahaan dalam bersikap terkait balasan yang bisa saja dihadapi pelapor usai melaporkan, dan (3) Probabilitas pembocoran informasi pelaporan kecurangan ke pihak eksternal perusahaan.

\section{Efektivitas Mekanisme Corporate Governance pada Perusahaan yang Memiliki Whistleblowing Policy}

Pengaduan yang diidentifikasi tidak hanya berkaitan langsung dengan penipuan, melainkan juga Earnings Management. Sehingga Whistleblowing Policy merupakan mekanisme yang efektif untuk mengurangi Earnings Management. Tanpa Whistleblowing Policy, manajemen dapat menyembunyikan praktik Earnings Management dan menyesatkan informasi keuangan pada pemegang saham.

Banyak penipuan perusahaan terungkap tidak hanya oleh auditor atau analis eksternal, tetapi juga oleh karyawan yang memiliki akses informasi akuntansi. Oleh karena itu, Whistleblowing Policy, sebagai salah satu mekanisme Corporate Governance, dapat meningkatkan aliran informasi ke direksi, khususnya, direksi independen, dan dengan demikian membantu mereka mendeteksi Earnings Management.

Oleh karena itu, dengan adanya Whistleblowing Policy yang efektif, auditor eksternal dan internal, antara lain, akan dengan mudah berkomunikasi dan mengangkat masalah apa pun yang terkait dengan kualitas pelaporan keuangan kepada direktur atau pemangku kepentingan lainnya, terutama tentang keterlibatan manajer dalam kegiatan Earnings Management. Dengan demikian, dengan adanya Whistleblowing Policy yang efektif, 
mekanisme Corporate Governance akan lebih efektif dalam mendeteksi praktik Earnings Management. Oleh karena itu, hipotesis dinyatakan sebagai berikut:

H1: Mekanisme Corporate Governance lebih efektif di perusahaan yang memiliki Whistleblowing Policy daripada perusahaan yang tidak memiliki Whistleblowing Policy

\section{METODE PENELITIAN}

\section{Desain Penelitian}

Studi ini menerapkan desain studi deskriptif-asosiatif untuk menggambarkan karakteristik dan mengidentifikasi kausalitas antarvariabel.

\section{Populasi dan Sampel}

Populasi dari studi ini adalah perusahaan manufaktur yang mendaftarkan diri di Bursa Efek Indonesia tahun 2016 sampai tahun 2018 yang mana terdapat 435 perusahaan yang sahamnya terdaftar di BEI.

Sampel dalam penelitian ini adalah perusahaan manufaktur yang terdaftar di Bursa Efek Indonesia tahun 2016-2018. Metode purposive sampling digunakan dalam pemilihan sampel pada penelitian ini, yakni berkriteria perusahaan dengan pendapatan negatif dalam satu tahun atau lebih dikeluarkan dari sampel.

\section{Metode Pengumpulan Data}

Data yang dipakai pada studi ini ialah pengumpulan data sekunder, yang dihimpun dari Bursa Efek Indonesia (BEI) dan juga IDX Statistik, website BEI yaitu www.idx.co.id. Sumber-sumber data yang difungsikan adalah laporan finansial tahunan perusahaan sampel. Dalam penelitian ini penulis dapat meninjau laporan keuangan tahunan yang diterbitkan oleh perusahaan dari tahun 2016-2018.

\section{Definisi Operasional Variabel}

Variabel-variabel didefinisikan pada Tabel 1 berikut ini.

Tabel 1. Definisi dan Pengukuran Variabel

\begin{tabular}{|c|c|}
\hline Variabel & Pengukuran \\
\hline DA & $\begin{array}{l}\text { Nilai absolut DA menggunakan } \\
\text { MJM }\end{array}$ \\
\hline BCIND & $\begin{array}{l}\text { "1" jika ketua dewan independen, } \\
\text { "0" sebaliknya }\end{array}$ \\
\hline BCTEN & $\begin{array}{l}\text { Jumlah tahun ketua dewan bekerja } \\
\text { di dewan direksi }\end{array}$ \\
\hline BSIZE & Jumlah dewan direksi \\
\hline BMEET & Jumlah rapat dewan per tahun \\
\hline BIND & $\begin{array}{l}\text { Proporsi independensi } \\
\text { dewan(persenan) }\end{array}$ \\
\hline BFEM & $\begin{array}{l}\text { "1" jika dewan memiliki direktur } \\
\text { wanita, "0" sebaliknya }\end{array}$ \\
\hline ACSIZE & Jumlah anggota Audit Committee \\
\hline ACMEET & $\begin{array}{l}\text { Jumlah pertemuan Audit Commitee } \\
\text { per tahun }\end{array}$ \\
\hline ACIND & $\begin{array}{l}\text { Proporsi independensi Audit } \\
\text { Committee }\end{array}$ \\
\hline ACFEM & $\begin{array}{l}\text { "1" dari Audit Commitee memiliki } \\
\text { direktur wanita, "0" sebaliknya }\end{array}$ \\
\hline ACAE & $\begin{array}{l}\text { Proporsi Audit Commitee dengan } \\
\text { keahlian akuntansi (persenan) }\end{array}$ \\
\hline ACMD & $\begin{array}{l}\text { Jumlah anggota Audit Commitee } \\
\text { yang merupakan direktur di } \\
\text { perusahaan lain }\end{array}$ \\
\hline Conc5 & $\begin{array}{l}\text { Proporsi saham dipegang oleh lima } \\
\text { pemegang saham terbesar(persenan) }\end{array}$ \\
\hline Big4 & $\begin{array}{l}\text { "1" jika perusahaan diaudit oleh Big } \\
4, \text { " } 0 \text { " sebaliknya }\end{array}$ \\
\hline FSIZE & Log alami dari total asset \\
\hline LEV & Total utang terhadap total asset \\
\hline ROA & Penghasilan bersih / total asset \\
\hline NCFO & $\begin{array}{l}\text { "1" jika perusahaan memiliki nilai } \\
\text { tunai negatif dari operasi, "0" } \\
\text { sebaliknya }\end{array}$ \\
\hline
\end{tabular}

Sumber: Data Diolah, 2020

\section{Teknik Analisis Data}

Analisis diterapkan secara deskriptif dan induktif. Model analisis yakni regresi data panel, ialah melalui pengkombinasian jenis data time-series dan cross-section (Ghozali \& Ratmono, 2013).

Pada analisis data panel, pengujian diujikan melalui: 
1. Uji Chow atau Likelyhood digunakan untuk pemilihan antara model fixed effect dan common effect.

2. Uji Hausman dipakai guna memilih model yang paling tepat untuk diimplementasikan, apakah fixed effect atau random effect.

\section{Uji Asumsi Klasik}

Pengujian asumsi klasik yang diterapkan meliputi pengujian normalitas. Implementasi uji normalitas residual yang difungsikan ialah uji Jarque-Bera (JB). Fungsi uji JB yakni dalam rangka menguji penyebaran normal data bagi sampel besar (asymptotic). Pengecekan penyebaran data secara normalitas dapat dilaksanakan dengan dua cara yaitu pertama, ketika nilai Jarque-Bera <2, hal ini mengindikasikan data telah tersebar secara normal. Kedua, dengan $\alpha=5 \%$, ketika data sig $>0,05$ dengan demikian data berdistribusi normal, sebaliknya ketika sig <0,05 mengandung arti data tidak terdistribusi dengan normal.

\section{Uji Model}

Data yang sudah dihimpun selanjutnya diproses pengolahannya memanfaatkan software Eviews 8. Agar diketahui pengaruh variabel intervening terhadap variabel terikat dipakai model regresi linear berganda atas dasar persamaan sebagai berikut:

$\mathrm{DA}=\alpha+\beta_{1} \mathrm{BCIND}+\beta_{2} \mathrm{BCTEN}+\beta_{3} \mathrm{BSIZE}+\beta_{4}$ BMEET $+\beta_{5} \mathrm{BIND}+$ $\beta_{6}$ BFEM $+\beta_{7}$ ACSIZE $+\beta_{8}$ ACMEET $+\beta_{9}$ ACIND $+\beta_{10}$ ACFEM + $\beta_{11} \mathrm{ACAE}+\beta_{12} \mathrm{ACMD}+\beta_{13}$ Conc $5+\beta_{14}$ Big $4+\beta_{15}$ FSIZE $+\beta_{16}$ LEV $+\beta_{17} \mathrm{ROA}+\beta_{18} \mathrm{NCFO}+\varepsilon$.

$\begin{array}{cl}\text { Keterangan } & \\ \text { DA } & =\text { Discretionary } \\ & \text { accrual } \\ \text { BCIND } & \text { ketua dewan } \\ & \text { independen } \\ \text { BCTEN } & =\text { tahun ketua dewan } \\ & \text { bekerja di dewan } \\ & \text { direksi } \\ \text { BSIZE } & =\text { dewan direksi } \\ \text { BMEET } & =\text { rapat dewan per } \\ & \text { tahun } \\ \text { BIND } & \text { Proporsi } \\ & \text { independensi } \\ \text { dewan(persenan) }\end{array}$

\begin{tabular}{|c|c|}
\hline BFEM & $\begin{array}{l}\text { = dewan yang } \\
\text { memiliki direktur } \\
\text { wanita }\end{array}$ \\
\hline ACSIZE & $\begin{array}{l}=\text { anggota Audit } \\
\text { Committee }\end{array}$ \\
\hline ACMEET & $\begin{array}{l}=\text { pertemuan Audit } \\
\text { Commitee } \text { per tahun }\end{array}$ \\
\hline ACIND & $\begin{array}{l}=\text { Proporsi } \\
\text { independensi Audit } \\
\text { Committee }\end{array}$ \\
\hline ACFEM & $\begin{array}{l}=\text { Audit Commitee } \\
\text { yang memiliki } \\
\text { direktur wanita }\end{array}$ \\
\hline ACAE & $\begin{array}{l}=\text { Proporsi Audit } \\
\text { Commitee dengan } \\
\text { keahlian akuntansi }\end{array}$ \\
\hline ACMD & $\begin{array}{l}\text { = anggota Audit } \\
\text { Commitee yang juga } \\
\text { direktur di } \\
\text { perusahaan lain }\end{array}$ \\
\hline Conc5 & $\begin{array}{l}\text { = Proporsi saham } \\
\text { dipegang oleh lima } \\
\text { pemegang saham } \\
\text { terbesar }\end{array}$ \\
\hline Big4 & $\begin{array}{l}=\text { perusahaan yang } \\
\text { juga diaudit oleh Big } \\
4\end{array}$ \\
\hline FSIZE & $=$ total asset \\
\hline LEV & $\begin{array}{l}=\text { Total utang } \\
\text { terhadap total asset }\end{array}$ \\
\hline ROA & $\begin{array}{l}=\text { Penghasilan bersih } \\
\text { dibagi total asset }\end{array}$ \\
\hline $\mathrm{NCFO}$ & $\begin{array}{l}=\text { perusahaan yang } \\
\text { memiliki nilai tunai } \\
\text { negatif dari operasi }\end{array}$ \\
\hline
\end{tabular}

Uji Statistik F juga dilaksanakan guna melakukan pengujian apakah model regresi bisa diterapkan dalam rangka menaksir besarnya belanja modal. Koefisien Determinasi $\left(\mathrm{R}^{2}\right)$ difungsikan sebagai pengukuran seberapa jauh kapasitas variabel-variabel independen memberikan penjelasan atas variabel dependen.

Pengujian hipotesis dilaksanakan memakai distribusi t. Uji statistik untuk membuktikan pengujian apakah variabel independen mampu menjelaskan variabel dependen secara baik jika terpisah. Kriteria pengujian hipotesis dengan uji $\mathrm{t}$ adalah: 
1. Prob $<0,05$ maka variabel independen merupakan penjelas yang signifikan terhadap variabel dependen.

2. Prob $>0,05$ maka variabel independen bukan merupakan penjelas yang signifikan terhadap variabel dependen.

\section{HASIL DAN PEMBAHASAN}

\section{Hasil Analisis Deskriptif}

Hasil analisis deskriptif dapat dilihat pada Tabel 2 berikut ini.

Tabel 2. Analisis Deskriptif

\begin{tabular}{|c|c|c|c|c|c|}
\hline & $\mathbf{N}$ & Mean & Max & Min & $\begin{array}{c}\text { Std. } \\
\text { Deviasi }\end{array}$ \\
\hline ACAE & 231 & $\begin{array}{c}41441 \\
.36 \\
\end{array}$ & $\begin{array}{c}86976 . \\
00\end{array}$ & $\begin{array}{c}24343 . \\
00\end{array}$ & 12131.35 \\
\hline ACFEM & 231 & $\begin{array}{c}0 . \\
38904 \\
5\end{array}$ & 1 & 0 & 0.26529 \\
\hline ACIND & 231 & $\begin{array}{c}0.469 \\
211\end{array}$ & 0 & 1 & 0.39101 \\
\hline ACMD & 231 & $\begin{array}{c}0.342 \\
219 \\
\end{array}$ & 1 & 0 & 0.39162 \\
\hline ACMEET & 231 & $\begin{array}{c}25.17 \\
734 \\
\end{array}$ & 1 & 0 & 1.109881 \\
\hline ACSIZE & 231 & $\begin{array}{c}0.078 \\
122 \\
\end{array}$ & 0 & 0 & 0.130132 \\
\hline BCIND & 231 & $\begin{array}{c}61689 \\
.00\end{array}$ & 0 & 0 & 22291.01 \\
\hline BCTEN & 231 & $\begin{array}{c}51427 \\
.00\end{array}$ & 0 & 0 & 20131.00 \\
\hline BFEM & 231 & $\begin{array}{c}68910 \\
.07\end{array}$ & 0 & 1 & $\begin{array}{c}329171.0 \\
0\end{array}$ \\
\hline BIG4 & 231 & $\begin{array}{c}21.87 \\
87\end{array}$ & 0 & 1 & $\begin{array}{c}391072.1 \\
1\end{array}$ \\
\hline BIND & 231 & $\begin{array}{c}39029 \\
.00\end{array}$ & 0 & 1 & $\begin{array}{c}201211.2 \\
1\end{array}$ \\
\hline BMEET & 231 & $\begin{array}{c}12.78 \\
142\end{array}$ & 19 & 10 & $\begin{array}{c}2.189117 \\
0\end{array}$ \\
\hline BSIZE & 231 & $\begin{array}{c}5.789 \\
110\end{array}$ & 10 & 9 & 2.18911 \\
\hline CONC5 & 231 & $\begin{array}{c}45188 \\
.00 \\
\end{array}$ & $\begin{array}{c}86976 . \\
00 \\
\end{array}$ & $\begin{array}{c}23253 . \\
00\end{array}$ & 11190.60 \\
\hline DA & 231 & $\begin{array}{c}20.56 \\
199 \\
\end{array}$ & $\begin{array}{c}454.77 \\
84 \\
\end{array}$ & $\begin{array}{c}564.70 \\
14\end{array}$ & 32.16101 \\
\hline LEV & 231 & $\begin{array}{c}8.342 \\
29 \\
\end{array}$ & 1 & 0 & 1.551911 \\
\hline FSZE & 231 & $\begin{array}{c}21.77 \\
912\end{array}$ & $\begin{array}{c}27.526 \\
97\end{array}$ & $\begin{array}{c}21.963 \\
93\end{array}$ & 1.134180 \\
\hline NCFO & 231 & 0 & 1 & 0 & 0.201853 \\
\hline ROA & 231 & $\begin{array}{c}0.234 \\
336\end{array}$ & $\begin{array}{c}0.8986 \\
80\end{array}$ & $\begin{array}{c}0.0013 \\
26\end{array}$ & $\begin{array}{c}0.117819 \\
2\end{array}$ \\
\hline
\end{tabular}

Sumber: Data Diolah, 2020

Berdasarkan tabel 2 jumlah audit komite memiliki nilai rata-rata (mean) sebesar 41441.36, maximum sebesar 86976.00, dan minimum senilai 24343.00. Besarnya nilai mean corporate risk yang menjadi sampel dalam penelitian adalah 0.389045 , nilai maksimalnya yaitu 1 dan nilai minimumnya senilai 0 . Besarnya nilai mean kompensasi rugi fiskal adalah 0.434409 , niai maksimum yaitu 1 , dan nilai minimum yaitu 0 . Besarnya nilai mean dari leverage senilai 0.488911 , nilai maksimumnya sebesar 5.488513, dan nilai minimumnya sebesar 0.000103 . Besarnya nilai mean ukuran perusahaan (size) yang pengukurannya menggunakan logaritma natural sebesar 28.14234, nilai maksimalnya sebesar 32.15098, dan memiliki nilai minimumnya sebesar 18.68498. Nilai mean dari return on asset adalah senilai 0.089403 , nilai maksimumnya senilai 1.032874 , serta nilai minimumnya senilai 0.000431 .

\section{Hasil Uji Normalitas}

Tabel 3. Uji Normalitas

\begin{tabular}{cc}
\hline \multicolumn{2}{c}{ Series: Standardized Residuals } \\
Sample 2016 2018 \\
Observations 234 \\
\hline Jarque-Bera & 260.4127 \\
Probability & 0.00000 \\
\hline
\end{tabular}

Sumber: Data Diolah, 2020

Merujuk pada Tabel 3 dapat ditinjau bahwa residual data tidak berdistribusi berdasarkan normalitas sebab nilai JarqueBera 260.4127 melebihi 2 dan nilai probabilitasnya $0.00000<0.05$. Pada studi ini jumlah observasi 231, yakni sebanyak 77 perusahaan dikali 3 tahun. Dengan demikian, sebagaimana dinyatakan oleh Gujarati (2007) yaitu studi ini mengandung set data yang melebihi standar yaitu 30 data, maka asumsi normalitas tidak terlalu dipermasalahkan.

\section{Hasil Uji Kelayakan Estimasi Regresi Data Panel}

1. Hasil Uji Chow Test

Tabel 4. Hasil Uji Chow 


\begin{tabular}{lccc}
\hline \multicolumn{1}{c}{ Effects Tests } & & & \\
Equation: Untitled \\
$\begin{array}{l}\text { Test cross-section } \\
\text { fixed effects }\end{array}$ & & & \\
\hline Effects Test & Statist & d.f. & Prob. \\
& ic & & \\
Cross-section F & 0.566 & $-55,560$ & 0.000 \\
& 900 & & \\
Cross-section Chi- & 77.27 & 81 & 0.000 \\
square & 116 & & \\
\hline Sumber: Data Diolah, 2020 & & \\
\end{tabular}

Tabel 4 dapat ditinjau bahwa besarnya Prob. Cross-section F senilai 0,0000 , nilai tersebut memperlihatkan nilai $<0,05$ (tingkat signifikansi studi ini). Mengacu pada hasil Uji Chow ditarik konklusi bahwa di antara metode common effect dan fixed effect, maka metode yang paling tepat untuk diterapkan yakni metode fixed effect.

Model fixed effect lebih tepat dipakai pada penelitian ini, namun disebabkan pada data panel masih adanya satu metode pendekatan lainnya yakni random effect, dengan demikian perlu dikomparasikan antara dua metode tersebut. Hasil mengkomparasikan dua metode tersebut ialah agar ditemukan metode paling tepat dalam melakukan estimasi data panel pada studi ini. Dalam rangka melakukan perbandingan dua metode tersebut maka difungsikan Uji Hausman.

\section{Uji Hausman Test}

\section{Tabel 5. Hasil Uji Hausman}

\begin{tabular}{llll}
\hline \multicolumn{2}{l}{ Correlated Random Effects - Hausman test } & \\
Equation: Untitled & & \\
Test cross-section random effects & & \\
\hline Test Summary & Chi-Sq. & Chi-Sq. & Prob. \\
& Statistic & d.f. &
\end{tabular}

\begin{tabular}{llll}
\hline Cross-section random & 15.523188 & 5 & 0.0049 \\
\hline
\end{tabular}

Sumber: Data Diolah, 2020

Tabel 5 merupakan tabel uji hausman yang menunjukkan probabilitas chi-square lebih kecil dari tingkat signifikansi yang digunakan $(0.0049$ < nilai sig. $\alpha 0,05)$ sehingga antara fixed effect dan random effect, model yang efisien digunakan pada penelitian ini adalah fixed effect model.

\section{Hasil Analisis Data Panel}

Metode yang terpilih untuk digunakan dalam penelitian ini adalah Random Effect. Hasil Regresi Fixed Effect dalam tabel berikut:

Tabel 6. Hasil Regresi Fixed Effect

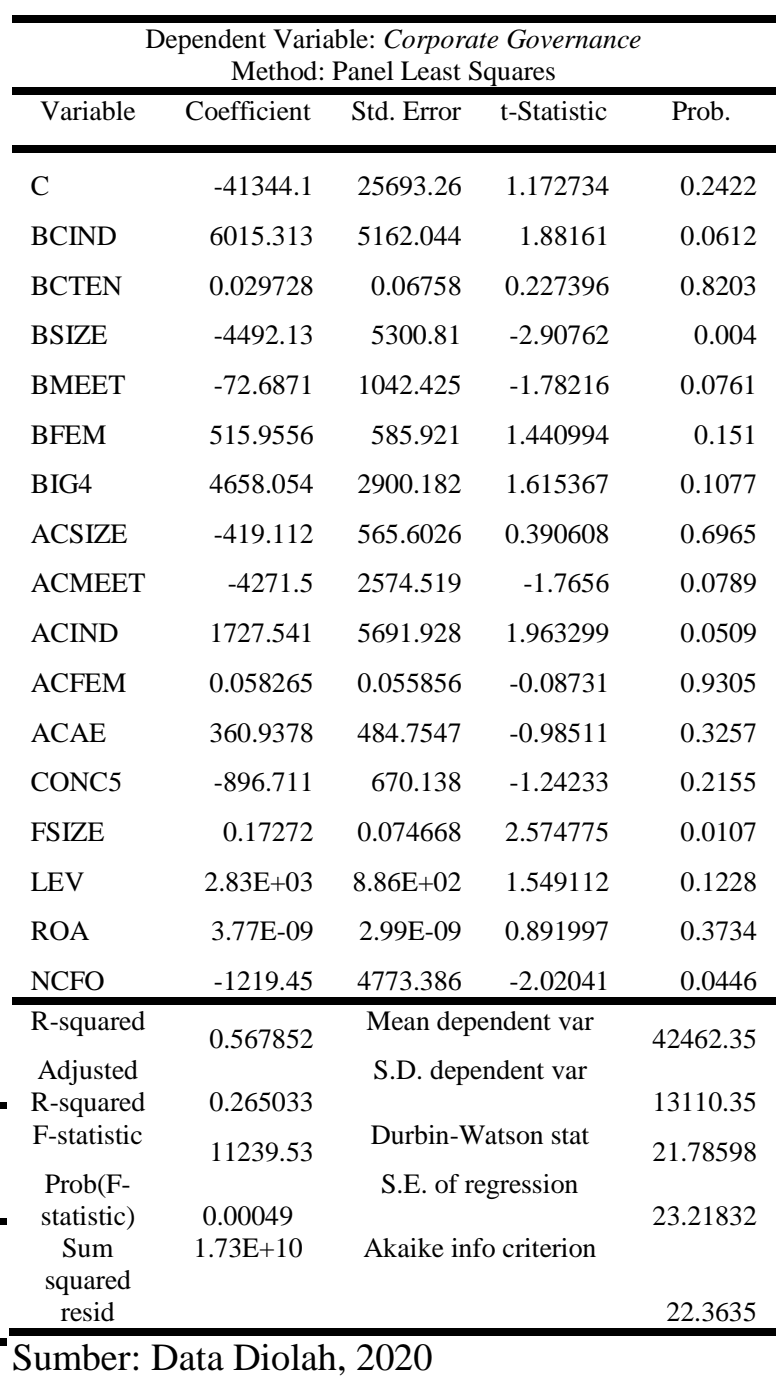

Sumber: Data Diolah, 2020

Merujuk pada hasil kalkulasi analisis rasio pada annual report perusahaan manufaktur yang terdaftar di BEI selama tiga tahun (2016-2018) maka dilakukan pengujian hipotesis dengan hasil analisis regresi yang disajikan pada tabel 6 maka menunjukkan bersarnya koefisien determinasi $\left(\mathrm{R}^{2}\right)$ sebesar 0,56852 yang 
berarti yang berarti delapan belas variabel independen mampu menjelaskan $56.78 \%$ sedangkan sisanya $65.43 \%$ dijelaskan oleh variabel lain yang tidak diteliti.

Hasil analisis terhadap nilai $\mathrm{F}$ statistic menunjukan sebesar 0.795986 dengan probabilitas 0.00057 . Karena probabilitas jauh di bawah 0.05 , maka dapat disimpulkan bahwa kedelapan belas variabel independen dalam penelitian ini berpengaruh terhadap Earnings Management.

Sebelum terjadi Whistleblowing Policy, dapat dilihat hasil regresi fixed effect seperti berikut.

Tabel 7. Hasil Regresi Fixed Effect Sebelum Whistleblowing Policy

\begin{tabular}{|c|c|c|c|c|}
\hline \multicolumn{5}{|c|}{$\begin{array}{c}\text { Dependent Variable: Corporate Governance } \\
\text { Method: Panel Least Squares }\end{array}$} \\
\hline Variable & Coefficient & Std. Error & t-Statistic & Prob. \\
\hline $\mathrm{C}$ & -41344.1 & 25693.26 & -1.60914 & 0.1099 \\
\hline ACFEM & 6015.313 & 5162.044 & 1.165297 & 0.2459 \\
\hline ACIND & 0.029728 & 0.06758 & 0.439889 & 0.6607 \\
\hline ACMD & -4492.13 & 5300.81 & -0.84744 & 0.3982 \\
\hline ACMEET & -72.6871 & 1042.425 & -0.06973 & 0.9445 \\
\hline ACSIZE & 515.9556 & 585.921 & 0.880589 & 0.3801 \\
\hline BCIND & 4658.054 & 2900.182 & 1.606125 & 0.1105 \\
\hline BCTEN & -419.112 & 565.6026 & -0.741 & 0.46 \\
\hline BFEM & -4271.5 & 2574.519 & -1.65914 & 0.0994 \\
\hline BIG4 & 1727.541 & 5691.928 & 0.303507 & 0.762 \\
\hline BIND & 0.058265 & 0.055856 & 1.04313 & 0.2987 \\
\hline BMEET & 360.9378 & 484.7547 & 0.744578 & 0.4578 \\
\hline BSIZE & -896.711 & 670.138 & -1.3381 & 0.1831 \\
\hline CONC5 & 0.17272 & 0.074668 & 2.313153 & 0.0222 \\
\hline FSIZE & $2.83 \mathrm{E}+03$ & $8.86 \mathrm{E}+02$ & 3.187546 & 0.0018 \\
\hline LEV & $3.77 \mathrm{E}-09$ & 2.99E-09 & 1.259655 & 0.2099 \\
\hline $\mathrm{NCFO}$ & -1219.45 & 4773.386 & -0.25547 & 0.7987 \\
\hline R-squared & \multicolumn{3}{|c|}{ Mean dependent var } & 42462.35 \\
\hline Adjusted & \multicolumn{4}{|c|}{ S.D. dependent var } \\
\hline R-squared & 0.265033 & \multirow{2}{*}{\multicolumn{2}{|c|}{ Durbin-Watson stat }} & 13110.35 \\
\hline F-statistic & 1.875218 & & & 2.691259 \\
\hline $\begin{array}{l}\text { Prob(F- } \\
\text { statistic) }\end{array}$ & 0.000364 & \multicolumn{2}{|c|}{ S.E. of regression } & 11239.53 \\
\hline $\begin{array}{l}\text { Sum } \\
\text { squared } \\
\text { resid }\end{array}$ & 17300000 & \multicolumn{2}{|c|}{ Akaike info criterion } & 21.78598 \\
\hline
\end{tabular}

Sumber: Data Diolah, 2020
Berdasarkan hasil perhitungan analisis rasio pada annual report perusahaan manufaktur yang terdaftar di BEI selama tiga tahun (2016-2018) maka dilakukan pengujian hipotesis dengan hasil analisis regresi sebelum WHBLT yang disajikan pada tabel 7 maka menunjukkan bersarnya koefisien determinasi $\left(\mathrm{R}^{2}\right)$ sebesar 0,567852 yang berarti yang berarti delapan belas variabel independen mampu menjelaskan $56.78 \%$ sedangkan sisanya $43.22 \%$ dijelaskan oleh variabel lain yang tidak diteliti.

Hasil analisis terhadap nilai $\mathrm{F}$ statistik menunjukan sebesar 1.875218 dengan probabilitas 0.00037 . Karena probabilitas jauh di bawah 0.05 , maka dapat disimpulkan bahwa kedelapan belas variabel independen dalam penelitian ini berpengaruh terhadap Earnings Management.

\section{Hubungan Corporate Governance dengan Earnings Management}

Whistleblowing Policy memiliki peran yang penting terhadap Earnings Management karena dengan adanya Whistleblowing Policy dapat memberikan meningkatkan aliran informasi ke direksi, khususnya, direksi independen, dan dengan demikian membantu mereka mendeteksi adanya Earnings Management.

Sebelum dimasukkan, dari penelitian ini sebelum terjadinya Whistleblowing Policy memiliki nilai yang berpengaruh positif dengan Earnings Management 0,567852 yang berarti delapan belas variabel independen mampu menjelaskan $56.78 \%$ sedangkan sisanya $43.22 \%$ dijelaskan oleh variabel lain yang tidak diteliti dan dengan probabilitas 0.00037. Karena probabilitas jauh di bawah 0.05 , maka dapat disimpulkan bahwa kedelapan belas variabel independen dalam penelitian ini berpengaruh terhadap Earnings Management. Hal ini berarti aliran informasi sebelum terjadi 


\section{KESIMPULAN}

Konklusi yang dihasilkan dari hasil analisis studi ini yakni mekanisme Corporate Governance lebih efektif diterapkan di perusahaan yang memiliki Whistleblowing Policy daripada perusahaan yang tidak memiliki Whistleblowing Policy. Aliran informasi sebelum diterapkannya Whistleblowing Policy memiliki pengaruh signifikan. Whistleblowing Policy memiliki peran yang penting terhadap Earnings Management karena dengan adanya Whistleblowing Policy dapat memberikan meningkatkan aliran informasi ke direksi, khususnya, direksi independen, dan dengan demikian membantu mereka mendeteksi adanya Earnings Management. Demikian halnya dengan size dan leverage perusahaan yang juga berpengaruh signifikan terhadap Earnings Management. Sedangkan tidak terdapat pengaruh jumlah komisaris independen terhadap Earnings Management.

\section{DAFTAR PUSTAKA}

Amri, G. (2008). Pedoman Sistem Pelaporan Pelanggaran - SPP (Whistleblower System - WSB).

Brandon, J. R. (2013). Whistle-blowing (I). Cambdridge University Press.

Daniri, A. (2007). Standarisasi Tanggung Jawab Sosial Perusahaan. Bisnis Indonesia.

Francis, J., Nanda, D., \& Olsson, P. (2008). Voluntary disclosure, earnings quality, and cost of capital. Journal of Accounting Research, 46(1), 53-99.

Ghozali, I., \& Ratmono, D. (2013). Analisis Multivariat dan Ekonometrika Teori, Konsep, dan Aplikasi dengan Eviews 8. Badan Penerbit Universitas Dipenogoro.

Husnan, S., \& Pudjiastuti, E. (2012). Dasar-dasar Manajemen Keuangan. UPP STIM YKPN.

KNKG. (2008). Pedoman Umum Good Corporate Governance Indonesia. Komite Nasional Kebijakan Governance.
Muhammad, R. (2015). Pengaturan dan Urgensi Whistle Blower dan Justice Collaborator dalam Sistem Peradilan Pidana. Jurnal Hukum IUS QUIA IUSTUM, 2(22), 203-222. 